www.jmscr.igmpublication.org Impact Factor 5.84

Index Copernicus Value: 83.27

ISSN (e)-2347-176x ISSN (p) 2455-0450

crossref DOI: _https://dx.doi.org/10.18535/jmscr/v5i4.120

Journal Of Medical Science And Clinical Research

\title{
Biochemical Evaluation of Anti-inflammatory Effect of Parsley Oil in Biliary Colic
}

\author{
Authors \\ Hussein A. Abd El-Maksoud ${ }^{1}$, Lobna M. Salem², Mohammed Abdullah ${ }^{3}$ \\ Mohamed G. El-Harrif ${ }^{4 *}$ \\ ${ }^{1,4}$ Department of Biochemistry, Benha University, Egypt \\ ${ }^{2}$ Department of Zoonosis, Benha University, Egypt \\ ${ }^{3}$ Department of Biochemistry, October 6 University, Egypt
}

\begin{abstract}
Biliary colic is an abdominal pain usually resulted from cholelithiasis and gallstones. Parsley (Petroselinum crispum) derived from the Umbelliferae family is one of the most consumed herbs due to its aromatic properties. The aim of this study was to evaluate the anti inflammatory effect of parsley in biliary colic. In order to achieve this aim 40 male albino rats was divided into three groups, healthy control group, non treated induced biliary colic group and parsley oil treated biliary colic group. The result of the present study showed a significant increase of inflammatory biomarkers IL2, IL6, TNF, histamine and cortisol in biliary colic group. The result also showed a significant decrease in inflammatory biomarkers IL2, IL6, TNF, histamine and cortisol in biliary colic group after administration of parsley oil. In conclusion we suggested that parsley can relief the pain resulted from cholelithiasis and gallstones through its anti-inflammatory properties.

Keywords: Biliary colic, Parsley, Anti-inflammatory.
\end{abstract}

\section{Introduction}

Biliary colic is the term used for gallbladder pain usually a rise from contraction of gallbladder against obstruction or passage of the stones through the biliary duct. Pain is usually perceived in the right upper quadrant or epigastrium. (Johnsto et al.,2014) The abdominal pain lasts minutes to hours, usually followed by nausea and vomiting.(Philip, 2010)

The most susceptible people to gallstones formation are female gender, elders and a family history for gallstone disease. Obesity is another risk factor contributing to the metabolic syndrome such as dyslipidemia (in particular hyper- lipoproteinemia type IV with hypertriglyceridemia and low HDL cholesterol), for the development of gallstones. Estrogen treatment enhances the risk, both in women when used for anti conception or hormone replacement and in men with prostatic cancer. Among specific dietary factors, short-time high cholesterol as well as high-carbohydrate diets were associated with increased risk for gallstones. (Marschall et al., 2007)

Eighty percent of gallstones are cholesterol stones while about ten percent are brown pigment stone and the remaining are black pigment stone. Three main mechanisms involved in stone formation 
which are cholesterol super saturation of bile, gallbladder hypo motility and kinetic, pro nucleating protein factors. Gururaja et al., 2014 Acute cholecystitis is an inflammation of the gallbladder that is due to biliary obstruction of the cystic duct by gallstones. This obstruction causes intraluminal pressure within the gallbladder and triggers an acute inflammatory response. Peiet al., 2013

Parsley (Petroselinum crispum) from the Umbelliferae family is one of the most consumed herbs due to its aromatic properties. (Catunescu et al., 2017).It contains many biologically active compounds such as phenolic compounds, especially flavonoids (e.g., apigenin, apiin), coumarins, and essential oil compound (mainly myristicin and apiol). Moreover, ascorbic acid, tocopherols, and carotenoids also present in parsley. (Abdellatief et al., 2017)

Parsley exhibit many pharmacological properties, including antioxidant, hepato protective, and cardio protective effects, in addition to nephroprotective, antidiabetic, analgesic, spasmolytic, antiplatelet, laxative, diuretic, antibacterial, antifungal and anti-inflammatory activities. (Farzaei et al., 2013)

\section{Objective of the Research}

The main objective of the present study was to evaluate anti-inflammatory effect of parsley oil in biliary colic.

\section{Material and Methods}

Healthy adult male albino rats, 8-10 weeks old, and average body weight 150 - 200 gm were used in the experimental investigation of this study. Rats were obtained from the Laboratory Animals Research Center, Benha University and used in accordance with the local ethics committee of Benha University for the use and care of animals in accordance with the NIH recommendations.

Animals were housed in separate metal cages, exposed to good ventilation, humidity and to a 12hr. light/dark cycle. Fresh and clean drinking water was supplied ad-libtium. Constant supplies of standard pellet diet, fresh and clean drinking water were supplied ad-libitum.

The animals were left for 15 days for acclimatization prior to the beginning of the experiment, and kept at constant environmental and nutritional conditions throughout the period of the experiment.

Rats are randomly divided into three main groups, placed in individual cages and classified as follow:

First group (Control group): consist of 10 male rats, were fed on normal diet and fresh, clean drinking water and Kept as control group.

Second group (biliary colic group): consist of 15 male rats were fed on normal diet supplemented with $0.5 \%$ cholesterol (w/w), $0.15 \%$ lecithin and $0.5 \%$ sodium desoxy cholate $(\mathrm{w} / \mathrm{w})$ for 6 weeks for induction of biliary colic and development of biliary stones and kept as positive control group.

Third group (Parsley treated group) consist of 15 rats with biliary colic treated with parsley oil $(0.5 \mathrm{ml} / \mathrm{kg})$ for 6 weeks.

\section{Blood Sampling}

Blood samples were collected from medial can thus of the eye of all animal groups in dry, clean screw capped tube, separated and centrifuged at 2500 r.p.m for 15 mints. The clean, clear serum was separated by Pasteur pipette and kept in a deep freeze at $-20 \mathrm{C}$ until used for determination of Tumor necrosis factor - $\alpha$ (TNF- $\alpha)$, Interlukin-1 (IL-1), Interlukin-6 (IL-6), Histamine, Cortisol.

\section{Statistical Analysis}

All values were expressed as mean \pm standard error (SE). All statistical analyses were performed using SPSS (version 19). Statistical differences among the experimental groups were assessed by ANOVA. Duncan's test was used as a follow-up test and significance was defined at $\mathrm{p}<0.05$.

\section{Results and Discussion}

The mean value of serum cortisol level in biliary colic group was significantly increased $(\mathrm{P}<0.05)$ on comparison with healthy control group. The 
mean value of serum cortisol level of parsley treated group was significantly increased $(\mathrm{P}<0.05)$ on comparison with healthy control and significantly decreased $(\mathrm{P}<0.05)$ on comparison with biliary colic group. Table (1)

The mean value of serum histamine level in biliary colic group was significantly increased $(\mathrm{P}<0.05)$ on comparison with healthy control group. The mean value of serum histamine level of parsley treated group was significantly increased $(\mathrm{P}<0.05)$ on comparison with healthy control and significantly decreased $(\mathrm{P}<0.05)$ on comparison with biliary colic group. Table (2)

The mean value of serum IL2 level in biliary colic group was significantly increased $(\mathrm{P}<0.05)$ on comparison with healthy control group. The mean value of serum IL2 level of parsley treated group was significantly increased $(\mathrm{P}<0.05)$ on comparison with healthy control and significantly decreased $(\mathrm{P}<0.05)$ on comparison with biliary colic group. Table (3)

The mean value of serum IL6 level in biliary colic group was significantly increased $(\mathrm{P}<0.05)$ on comparison with healthy control group. The mean value of serum IL6 level of parsley treated group was significantly increased $(\mathrm{P}<0.05)$ on comparison with healthy control and significantly decreased $(\mathrm{P}<0.05)$ on comparison with biliary colic group. Table (4)

The mean value of serum TNF $\alpha$ level in biliary colic group was significantly increased $(\mathrm{P}<0.05)$ on comparison with healthy control group. The mean value of serum TNF $\alpha$ level of parsley treated group was significantly increased $(\mathrm{P}<0.05)$ on comparison with healthy control and significantly decreased $(\mathrm{P}<0.05)$ on comparison with biliary colic group. Table (5)

Table (1): The mean values \pm S.E of serum (Cortisol) in healthy control, biliary colic, biliary colic with parsley groups

\begin{tabular}{|c|c|c|c|c|c|c|c|}
\hline \multirow{2}{*}{ Group } & \multicolumn{6}{|c|}{ Period (week) } & \multirow{2}{*}{ Mean } \\
\hline & 1 & 2 & 3 & 4 & 5 & 6 & \\
\hline G1 & $7.36 \pm 0.37^{\mathrm{cA}}$ & $7.25 \pm 0.40^{\mathrm{dA}}$ & $7.41 \pm 0.33^{\mathrm{dA}}$ & $7.05 \pm 0.39^{\mathrm{dA}}$ & $7.62 \pm 0.31^{\mathrm{dA}}$ & $7.35 \pm 0.93^{\mathrm{dA}}$ & $7.34 \pm 0.18^{\mathrm{d}}$ \\
\hline $\mathrm{G} 2$ & $25.85 \pm 3.11^{\mathrm{aE}}$ & $35.33 \pm 3.97^{\mathrm{aD}}$ & $43.39 \pm 5.32^{\mathrm{aC}}$ & $49.95 \pm 4.73^{\mathrm{aB}}$ & $52.87 \pm 6.28^{\mathrm{aB}}$ & $62.99 \pm 3.76^{\mathrm{a} A}$ & $45.06 \pm 3.02^{\mathrm{a}}$ \\
\hline G3 & $23.00 \pm 2.79^{\mathrm{aC}}$ & $28.56 \pm 4.31^{\mathrm{bB}}$ & $31.81 \pm 3.16^{\mathrm{bB}}$ & $38.93 \pm 3.13^{\mathrm{bA}}$ & $38.30 \pm 2.52^{\mathrm{bA}}$ & $42.22 \pm 2.30^{\mathrm{bA}}$ & $33.80 \pm 1.78^{b}$ \\
\hline
\end{tabular}

G1: Control healthy group G2: Control biliary colic group $\quad$ G3: Biliary colic + parsley treated group

$\mathrm{a}, \mathrm{b} \& \mathrm{c}$ : There is no significant difference $(\mathrm{P}>0.05)$ between any two means, within the same column have the same superscript letter.

A, B \& C: There is no significant difference $(\mathrm{P}>0.05)$ between any two means for the same attribute, within the same row have the same superscript letter.

Table (2): The mean values \pm S.E of serum (Histamine) in healthy control, biliary colic, biliary colic with parsley groups.

\begin{tabular}{|c|c|c|c|c|c|c|c|}
\hline \multirow{2}{*}{ Group } & \multicolumn{6}{|c|}{ Period (week) } & \multirow{2}{*}{ Mean } \\
\hline & 1 & 2 & 3 & 4 & 5 & 6 & \\
\hline G1 & $2.11 \pm 0.26^{\mathrm{cA}}$ & $2.19 \pm 0.36^{\mathrm{cA}}$ & $2.89 \pm 0.19^{\mathrm{dA}}$ & $2.57 \pm 0.24^{\mathrm{cA}}$ & $1.79 \pm 0.55^{\mathrm{cA}}$ & $1.42 \pm 0.30^{\mathrm{cA}}$ & $2.16 \pm 0.16^{\mathrm{c}}$ \\
\hline $\mathrm{G} 2$ & $9.47 \pm 1.03^{\mathrm{abD}}$ & $11.53 \pm 0.47^{\mathrm{aD}}$ & $14.71 \pm 2.75^{\mathrm{aC}}$ & $19.56 \pm 1.84^{\mathrm{aB}}$ & $20.84 \pm 4.89^{\mathrm{aB}}$ & $36.17 \pm 4.43^{\mathrm{aA}}$ & $18.71 \pm 2.14^{\mathrm{a}}$ \\
\hline G3 & $7.56 \pm 0.82^{\mathrm{bB}}$ & $7.69 \pm 0.57^{\mathrm{bB}}$ & $7.59 \pm 0.88^{\mathrm{cB}}$ & $11.04 \pm 0.64^{\mathrm{bA}}$ & $11.08 \pm 0.61^{\mathrm{bA}}$ & $11.42 \pm 0.48^{\mathrm{bA}}$ & $9.40 \pm 0.45^{b}$ \\
\hline
\end{tabular}

G1: Control healthy group G2: Control biliary colic group G3: Biliary colic + parsley treated group

$\mathrm{a}, \mathrm{b} \& \mathrm{c}$ : There is no significant difference $(\mathrm{P}>0.05)$ between any two means, within the same column have the same superscript letter.

A, B \& C: There is no significant difference $(\mathrm{P}>0.05)$ between any two means for the same attribute, within the same row have the same superscript letter. 
Table (3): The mean values \pm S.E of serum (IL2) in healthy control, biliary colic, biliary colic with parsley groups.

\begin{tabular}{|l|c|c|c|c|c|c|c|}
\hline \multirow{2}{*}{ Group } & \multicolumn{5}{|c|}{ Period (week) } & \multirow{2}{*}{ Mean } \\
\cline { 2 - 8 } & 1 & 2 & 3 & 4 & 5 & 6 & \\
\hline G1 & $0.51 \pm 0.14^{\mathrm{abA}}$ & $0.28 \pm 0.06^{\mathrm{cA}}$ & $0.36 \pm 0.11^{\mathrm{cA}}$ & $0.46 \pm 0.08^{\mathrm{cA}}$ & $0.38 \pm 0.1^{\mathrm{cA}}$ & $0.54 \pm 0.16^{\mathrm{CA}}$ & $0.42 \pm 0.05^{\mathrm{C}}$ \\
\hline G2 & $0.71 \pm 0.12^{\mathrm{aE}}$ & $1.32 \pm 0.28^{\mathrm{aD}}$ & $1.57 \pm 0.20^{\mathrm{aD}}$ & $2.05 \pm 0.45^{\mathrm{aC}}$ & $2.44 \pm 0.17^{\mathrm{aB}}$ & $2.97 \pm 0.46^{\mathrm{a}} \mathrm{A}$ & $1.84 \pm 0.19^{\mathrm{a}}$ \\
\hline G3 & $0.46 \pm 0.13^{\mathrm{bB}}$ & $0.72 \pm 0.13^{\mathrm{bAB}}$ & $0.83 \pm 0.06^{\mathrm{bA}}$ & $0.79 \pm 0.05^{\mathrm{bA}}$ & $0.78 \pm 0.11^{\mathrm{bA}}$ & $0.90 \pm 0.04^{\mathrm{b}} \mathrm{A}$ & $0.75 \pm 0.04^{\mathrm{b}}$ \\
\hline
\end{tabular}

G1: Control healthy group $\quad$ G2: Control biliary colic group $\quad$ G3: Biliary colic + parsley treated group

$\mathrm{a}, \mathrm{b} \& \mathrm{c}$ : There is no significant difference $(\mathrm{P}>0.05)$ between any two means, within the same column have the same superscript letter.

A, B \& C: There is no significant difference $(\mathrm{P}>0.05)$ between any two means for the same attribute, within the same row have the same superscript letter.

Table (4): The mean values \pm S.E of serum (IL6) in healthy control, biliary colic, biliary colic with parsley groups.

\begin{tabular}{|l|c|c|c|c|c|c|c|}
\hline \multirow{2}{*}{ Group } & \multicolumn{6}{|c|}{ Period (week) } & \multirow{2}{*}{ Mean } \\
\cline { 2 - 7 } & 1 & 2 & 3 & 4 & 5 & 6 & \\
\hline G1 & $6.48 \pm 0.46^{\mathrm{cA}}$ & $5.88 \pm 0.86^{\mathrm{dA}}$ & $5.82 \pm 0.55^{\mathrm{cA}}$ & $6.13 \pm 0.52^{\mathrm{dA}}$ & $6.38 \pm 1.03^{\mathrm{dA}}$ & $6.04 \pm 0.27^{\mathrm{dA}}$ & $6.12 \pm 0.25^{\mathrm{d}}$ \\
\hline G2 & $15.46 \pm 0.42^{\mathrm{aD}}$ & $28.28 \pm 2.68^{\mathrm{aC}}$ & $30.08 \pm 4.37^{\mathrm{aC}}$ & $35.80 \pm 2.26^{\mathrm{aB}}$ & $39.16 \pm 2.55^{\mathrm{aB}}$ & $47.47 \pm 6.79^{\mathrm{aA}}$ & $32.71 \pm 2.48^{\mathrm{a}}$ \\
\hline G3 & $9.25 \pm 0.67^{\mathrm{bE}}$ & $17.98 \pm 1.68^{\mathrm{bD}}$ & $18.55 \pm 2.79^{\mathrm{bD}}$ & $24.68 \pm 3.66^{\mathrm{bC}}$ & $32.46 \pm 4.87^{\mathrm{bB}}$ & $40.22 \pm 4.43^{\mathrm{bA}}$ & $23.86 \pm 2.44^{\mathrm{b}}$ \\
\hline
\end{tabular}

G1: Control healthy group $\quad$ G2: Control biliary colic group $\quad$ G3: Biliary colic + parsley treated group

$\mathrm{a}, \mathrm{b} \& \mathrm{c}$ : There is no significant difference $(\mathrm{P}>0.05)$ between any two means, within the same column have the same superscript letter.

A, B \& C: There is no significant difference $(\mathrm{P}>0.05)$ between any two means for the same attribute, within the same row have the same superscript letter.

Table (5): The mean values \pm S.E of serum (TNF $\alpha$ ) in healthy control, biliary colic, biliary colic with parsley groups.

\begin{tabular}{|l|c|c|c|c|c|c|c|}
\hline \multirow{2}{*}{ Group } & \multicolumn{5}{|c|}{ Period (week) } & \multirow{2}{*}{ Mean } \\
\cline { 2 - 8 } & 1 & 2 & 3 & 4 & 5 & 6 & \\
\hline G1 & $31.21 \pm 2.17^{\mathrm{CA}}$ & $33.19 \pm 2.15^{\mathrm{cA}}$ & $30.20 \pm 5.02^{\mathrm{dA}}$ & $28.61 \pm 4.21^{\mathrm{dA}}$ & $27.56 \pm 3.37^{\mathrm{dA}}$ & $27.92 \pm 1.22^{\mathrm{dA}}$ & $29.78 \pm 1.26^{\mathrm{d}}$ \\
\hline G2 & $63.42 \pm 12.03^{\mathrm{aD}}$ & $65.36 \pm 10.79^{\mathrm{aD}}$ & $80.85 \pm 14.10^{\mathrm{aC}}$ & $114.99 \pm 6.57^{\mathrm{aB}}$ & $121.03 \pm 4.22^{\mathrm{aB}}$ & $132.87 \pm 7.80^{\mathrm{aA}}$ & $96.42 \pm 6.77^{\mathrm{a}}$ \\
\hline G3 & $44.54 \pm 8.05^{\mathrm{bE}}$ & $47.81 \pm 10.35^{\mathrm{bCDE}}$ & $42.80 \pm 7.70^{\mathrm{CE}}$ & $55.33 \pm 8.00^{\mathrm{CBCD}}$ & $57.33 \pm 4.60^{\mathrm{cBC}}$ & $72.67 \pm 5.18^{\mathrm{CA}}$ & $53.41 \pm 3.45^{\mathrm{C}}$ \\
\hline
\end{tabular}

G1: Control healthy group $\quad$ G2: Control biliary colic group $\quad$ G3: Biliary colic + parsley treated group

$\mathrm{a}, \mathrm{b} \& \mathrm{c}$ : There is no significant difference $(\mathrm{P}>0.05)$ between any two means, within the same column have the same superscript letter.

A, B \& C: There is no significant difference $(\mathrm{P}>0.05)$ between any two means for the same attribute, within the same row have the same superscript letter.

\section{Discussion}

Gallstone disease is one of the most prevalent gastrointestinal problems with over load on healthcare providers that is supposed to increase in old peoples (Marschall et al., 2007)

Our data showed that the mean value of serum histamine,IL2, IL6, cortisol and TNFa levels in biliary colic group was significantly increased $(\mathrm{P}<0.05)$ on comparison with healthy control group.

Cytokines are small protein mediators involved in inflammatory, metabolic, and immune modulatory functions. They are not only produced by monocytes, lymphocytes, fibroblasts, and endothelial cells, but also in hepatocytes and the biliary epithelium. Secreted inflammatory molecules, such as pro inflammatory cytokines, are among the critical mediators of the altered processes implicated in hepatobiliary disease.(Pei et al., 2013)

our results was in agreement with (Gotts et al., 2016) who reported that, in tissue inflammation, macrophages, damage-associated molecular patterns and release pro inflammatory cytokines. These include granulocyte colony stimulating factor, IL-1a, IL-6, IL-12, and tumor necrosis factor $\alpha(\mathrm{TNF}-\alpha)$.

(Savard et al., 2002) demonstrates that the biliary cytokine profile in vivo of acute cholecystitis is 
different from that in bacterial infection in vitro suggesting that IL- 8 and IL- $1 \beta$ have roles in the development of acute cholecystitis in humans. Also, several serum cytokine concentration (TNF $\alpha$, IL-6, IL-8, and IL-10) were increased in patients with acute cholangitis compared to a normal group, this indicate its relation to the systemic inflammatory response

The elevation of cytockines may directly reflect the local inflammatory status of the gallbladder. In addition, IL- 8 and IL-1 $\beta$ consistently remained at high levels during the entire period of acute cholecystitis. This suggests that IL- 8 and IL- $1 \beta$, could serve as constant and reliable indicators for patientswith acute cholecystitis. Pei et al., 2013 In addition, (Hoogerwerf et al.,2005)found that, about ten folds increasing inlamina propria and muscular is mucosa mast cells in children with biliary dyskinesia and symptomatic gallstones in the patients with gallstone and biliary type pain. It is possible that mastcells are associated with pain and would be less in asymptomatic gallstone patients

Gallbladder mast cells would have the potential relationto pain generation by two different mechanisms: sensitivity to distension as seen with mast cell degranulation in the gastrointestinal tract and through the generation of gallbladder spasms induced by mast cell products. For example, both histamine and cysteinyl leukotrienes increase the excitability of gallbladder smooth muscle and causing contraction Brian et al., 2006

Cortisol is a glucocorticoid hormone released by the hypothalamic pituitary adrenal (HPA) axis in response to inflammation through activation of the hypothalamic pituitary adrenalaxis by pro inflammatory cytokines, such as IL-6 leading to subsequent increase in plasma concentrations of cortisol. (Andrew et al., 2013)

Our result showed that the mean value of serum histamine, IL2, IL6, cortisol and (TNF $\alpha$ ) levels of parsley treated group was significantly increased $(\mathrm{P}<0.05)$ on comparison with healthy control and significantly decreased $(\mathrm{P}<0.05)$ on comparison with biliary colic group. parsley oil is rich with myristicin (32.75\%), apiol (17.54\%), $\alpha$ pinene (16.64\%), $\beta$ pinene $(11.54 \%)$ and1-allyl-2,3,4,5,-tetramethoxybenzene (10\%). (Mejdiet al., 2016)

in accordance with our data(David Hoffmann, 2010) revealed that parsley has been used for the treatment of inflammatory condition, liver diseases, constipation, flatulence, jaundice, colic pain, and rheumatism.

In addition (Shahbaa et al., 2015) showed that all the doses of parsley effectively suppressed the edema produced by histamine, which indicates that, parsley provides its anti-inflammatory action by means of either inhibiting the synthesis or inhibiting release of inflammatory mediators.

Also, (Jiet al., 2011) found that, myristicin (one of the most important constituent of parsley) at the concentration of $50 \mu \mathrm{M}$, significantly inhibit production of some cytokines such as TNF- $\alpha$, and IL-1 $\alpha$. So, myristicinis suggested to be applied in higher concentrations for evaluation of antiinflammatory effects concerned with TNF- $\alpha$, and IL- $1 \alpha$.

Moreover, (Kamatou et al., 2008) revealed that, the mechanisms of action of many phenolic compounds such as flavonoids and curcumins occur by free radical scavenging activities and inhibition of pro inflammatory enzymes such as cyclooxygenases and lipoxygenases in the inflammatory process.

Furthermore,(Farzaei et al., 2013) showed that, Petroselinum crispum seed hydroalcoholic extract offer analgesic activity in mice by reducing $\mathrm{KCl}$ and $\mathrm{CaCl} 2$ induced contractions in ratsand the analgesic effect depends on blocking voltage gated calcium channels. Different extracts from aerial parts of parsley demonstrated antispasmodic activity on spontaneous and acetylcholine induced contractions of rat isolated ileum.

\section{Conclusion}

In conclusion, our results demonstrated the biliary colic accompany by increased level of serum inflammatory biomarkers and showed that the parsley can relief the biliary colic resulted from cholelithiasis and gallstones through its 
antiinflammtory properties. Further research is required about clear and exact mechanism of action of parsley oil in biliary colic.

\section{References}

1. Abdellatief S. A., Azza A.A. Galala, Sameh M. Farouk, Mohamed M. AbdelDaim, 2017 "Ameliorative effect of parsley oil on cisplatin-induced hepatocardiotoxicity: A biochemical, histopathological, and immunohistochemical study" Biomedicine \& Pharmacotherapy 86 482491

2. Andrew Schrepf a, Lauren Clevenger a, Desire Christensen a, KoenDeGeest b, David Bender b, Amina Ahmed b, Michael J. Goodheartb,c, LailaDahmoush d, Frank Penedo e, Joseph A. Lucci III f, ParvinGanjei-Azar g, Luis Mendez h, KristianMarkon a, David M. Lubaroffc,i,j, Premal H. Thaker k, George M. Slavich 1, Anil K. Soodm, Susan K. Lutgendorf(2013) "Cortisol and inflammatory processes in ovarian cancer patients following primary treatment: Relationships with depression, fatigue, and disability" Brain, Behavior, and Immunity 30 S126-S134

3. Ayman F. Khalil, Haiam O. Elkatry, Hanaa F. El Mehairy(2015) Protective effect of peppermint and parsley leaves oils against hepatotoxicity on experimental rats Annals of Agricultural Science" 60(2), 353-359

4. Brian Rau, Craig A. Friesen, James F. Daniel, Adnan Qadeer,Ding You-Li, Charles C. Roberts, George W. Holcom (2006) "Gallbladder wall inflammatory cells in pediatric patients with biliary dyskinesia and cholelithiasis: a pilot study" Journal of Pediatric Surgery 41, $1545-1548$

5. Cătunescu M.G, IoanRotar, Roxana Vidican, FlorinaBunghez, Ancuța M. Rotar, 2017 " Gamma radiation enhances the bioactivity of fresh parsley
(Petroselinumcrispum (Mill.) Fuss Var. Neapolitanum) Radiation Physics and Chemistry 132, 22-29

6. Farzaei M.H., Z. Abbasabadi, M.R. Ardekani, R. Rahimi, F. Farzaei, (2013) "Parsley: a review of ethnopharmacology, phytochemistry and biological activities" J. Tradit. Chin. Med. 33 815-826.

7. Gotts JE, Matthay MA. 2016 "Sepsis: pathophysiology and clinical management" BMJ.;353:i1585.

8. Gururaja MP, Anusha Raj, Himanshu Joshi, CS ShastryKalanchoe, 2014 "pinnatum in Treatment of Gallstones" An Ethnopharmacological Review Int.J.PharmTech Res.,6(1),pp 252-261.

9. Hoogerwerf WA, Gondesen K, Xiao S-Y, et al.,. 2005"The role of mast cells in the pathogenesis of pain in chronic pancreatitis. BMC Gastroenterology;5:8.

10. Ji Young Lee and Wansu Park (2011) Anti-Inflammatory Effect of Myristicin on RAW 264.7 Macrophages Stimulated with Polyinosinic-Polycytidylic Acid. Molecules, 16, 7132-7142

11. Johnsto M.J. n, J.E.F. Fitzgerald b, A. Bhangu, N.S. Greaves, C.L. Prew, I. Fraser (2014) "Outpatient management of biliary colic: A prospective observational study of prescribing habits and analgesia effectiveness" International Journal of Surgery 12 169-176

12. Kamatou, G.P., Makunga, N.P., Ramogola, W.P., Viljoen, A.M., 2008. South African Salvia species: a review of biological activities and phytochemistry" J. Ethnopharmacol. 119 (3), 664-672.

13. Marschall H-U, Einarsson C., 2007"Gallstone disease (Review)". J Intern Med; 261: 529-542.

14. MejdiSnoussi, AmeniDehmani, Emira Noumi, Guido Flamini, Adele Papetti (2016) "Chemical composition and antibiofilm activity of Petroselinum crispum and Ocimumbasilicum essential 
oils against Vibrio spp. Strains" Microbial Pathogenesis 90 13-21

15. Pei-Yuan Su, Shih-Jen Liu, Yi-Hua Chen , Shun-Sheng Wu, Yao-Li Chen, Jhin-Ran Ke , Cheng-Yuan Peng , YuhPyngSher2013"Increased IL-8 and IL-1b in the bile of acute cholecystitis patients" Bio Medicine 3, 181-185

16. Philip E. Jaffe2010"Biliary colic"Decision Making in Medicine (Third Edition), Pages 194-195

17. Savard CE, Blinman TA, Choi HS, Lee SK, Pandol SJ, Lee SP. 2002Expression of cytokine and chemokine mRNA and secretionof tumor necrosis factor-alpha by gallbladder epithelial cells:response to bacterial lipopolysaccharides. BMC Gastroenterol; 2:23

18. Shahbaa M. Al-khazraji (2015)," Studying the Analgesic, Anti-inflam-matory and Antipyretic Properties of The Aqueous Extract of Petroselinumcrispum in Experimental Animal Models" IOSR Journal Of Pharmacy 5, 9 17-23. 